\title{
Endothelin-1 Is Synthesized and Inhibits Cyclic Adenosine Monophosphate-dependent Anion Secretion by an Autocrine/Paracrine Mechanism in Gallbladder Epithelial Cells
}

\author{
Laura Fouassier, ${ }^{*}$ Thierry Chinet, ${ }^{\ddagger}$ Brigitte Robert, ${ }^{\S}$ Alain Carayon, \\ Raoul Poupon, ${ }^{\star \star \star}$ Jacqueline Capeau, ${ }^{*}$ Véronique Barbu, ${ }^{\star}$ and Chantal Housset ${ }^{\star \star \star}$ \\ *Unité Institut National de la Santé et de la Recherche Médicale U402, Faculté de Médecine Saint-Antoine, 75012 Paris, France; \\ ${ }^{\ddagger}$ Laboratoire de Biologie et Pharmacologie des Epithéliums Respiratoires, Hôpital Ambroise-Paré, 92100 Boulogne, France; ${ }^{\S}$ Unité \\ Institut National de la Santé et de la Recherche Médicale U361, Maternité Baudelocque, 75014 Paris, France; "Service de Biochimie, \\ Hôpital Pitié-Salpêtrière, 75013 Paris, France; "IService de Chirurgie Générale and **Service d'Hépato-Gastroentérologie, Hôpital \\ Saint-Antoine, 75012 Paris, France
}

\begin{abstract}
Ion and fluid transport across the biliary epithelium contributes to bile secretion. Since endothelin (ET)-1 affects ion transport activities and is released by human gallbladderderived biliary epithelial cells in primary culture, we examined the expression of ET peptides and ET receptors and the influence of ET-1 on ion transport in this epithelium ex vivo. In freshly isolated gallbladder epithelial cells, preproET-1, -2 , and -3 mRNAs were detected by reverse transcription PCR and ET-1 isopeptide was identified by chromatography. The cells also displayed ET receptor mRNAs and high-affinity binding sites for ET-1, mostly of the $\mathrm{ET}_{\mathrm{B}}$ type. Electrogenic anion secretion across intact gallbladder mucosa was stimulated by forskolin, secretin, and exogenous ATP, as assessed by short-circuit current (Isc) increases in Ussing-type chambers. ET-1 inhibited forskolin- and secretin-induced changes in Isc, without affecting baseline Isc or ATP-induced changes. Accordingly, ET-1 significantly reduced the accumulation of intracellular cAMP elicited by forskolin and secretin in the epithelial cells, and this effect was abolished by pertussis toxin. This is the first evidence that ET-1 is synthesized and inhibits, via a Gi protein-coupled receptor, cAMP-dependent anion secretion in human gallbladder epithelium, indicating a role in the control of bile secretion by an autocrine/paracrine mechanism. ( $J$. Clin. Invest. 1998. 101:2881-2888.) Key words: biliary tract • chlorides $\bullet \mathrm{G}$ protein, inhibitory $\mathrm{Gi} \cdot$ receptors, cell surface $\bullet$ secretin
\end{abstract}

Part of this work was presented at the annual meeting of the American Association for the Study of Liver Diseases on 3-7 November 1996 in Chicago, IL and at the annual meeting of the European Association for the Study of Liver on 9-12 April 1997 in London, UK.

Address correspondence to Dr. Chantal Housset, INSERM U402, Faculté de Médecine Saint-Antoine, 27 rue de Chaligny, 75571 Paris Cédex 12, France. Phone: 33-1-4001-1359; FAX: 33-1-40011499; E-mail: chantal.housset@st-antoine.inserm.fr

Received for publication 15 January 1998 and accepted in revised form 14 April 1998.

J. Clin. Invest.

(C) The American Society for Clinical Investigation, Inc. 0021-9738/98/06/2881/08 \$2.00

Volume 101, Number 12, June 1998, 2881-2888

http://www.jci.org

\section{Introduction}

The epithelium lining the intra- and extrahepatic biliary tract, including the gallbladder, actively modifies the volume and composition of bile, which is primarily elaborated by the hepatocytes $(1,2)$. The intrahepatic bile duct-forming cells secrete a bicarbonate-rich fluid, accounting for up to $40 \%$ of bile flow in humans (2). The gallbladder, known as a reservoir that stores and concentrates hepatic bile during fasting, contracts and secretes an alkaline, bicarbonate-rich fluid after feeding. Gallbladder contraction occurs in response to cholecystokinin, while secretin and vasoactive intestinal polypeptide act as biliary secretagogues. They both stimulate fluid secretion in the intrahepatic bile ducts $(3,4)$. They also induce the conversion of fluid transport from net absorption to net secretion across the gallbladder epithelium $(5,6)$, and their effects are mediated by cAMP $(7,8)$. In addition to these well-defined physiological regulators, it is increasingly evident that other hormones or transmitters such as somatostatin, acetylcholine, or extracellular ATP influence biliary epithelial cell function (2, 9 ). We raised the hypothesis that endothelin $(\mathrm{ET})^{1}-1$ may also contribute to the regulation of biliary epithelial cell function, since this peptide, like other vasoactive peptides including vasoactive intestinal polypeptide, vasopressin, and atrial natriuretic peptide, affects ion and fluid transport in other epithelia such as in the intestine, kidney, and lung epithelia (10-12).

ET-1 belongs to a family of three homologous peptides, ET-1, ET-2, and ET-3, first described as potent vasoconstrictors, but now known to exert an array of biological activities (13). ET isopeptides arise through proteolytic cleavage of peptidic precursors, the preproETs, which are encoded by three separate genes (13). Initially isolated from the conditioned medium of cultured endothelial cells, ET-1 was subsequently shown to be synthesized by several other cell types, while the cell origin of ET-2 and ET-3 has been poorly elucidated. The biological effects of the ETs are mediated by at least two types of receptors, $\mathrm{ET}_{\mathrm{A}}$ and $\mathrm{ET}_{\mathrm{B}}$, which both belong to the superfamily of $\mathrm{G}$ protein-coupled receptors $(14,15)$. These receptors exhibit distinct selectivity for ET isopeptides. The $\mathrm{ET}_{\mathrm{A}}$ receptor binds ET-1 and ET-2 with a higher affinity than ET-3, while $\mathrm{ET}_{\mathrm{B}}$ receptor displays similar affinities for all three isopeptides. Because ET receptors are often expressed by those cells that produce ET peptides, or in their vicinity (16), it

1. Abbreviations used in this paper: CFTR, cystic fibrosis transmembrane conductance regulator; ET, endothelin; G3PDH, glyceraldehyde-3-phosphate dehydrogenase; Isc, short-circuit current; RT, reverse transcription. 
is assumed that the ETs act predominantly by autocrine and/or paracrine routes.

We reported previously that biliary epithelial cells, including those of the gallbladder, exhibit ET immunoreactivity in vivo, and that ET-1 is released by human gallbladder-derived biliary epithelial cells in primary culture (17). These findings were consistent with ET synthesis in the gallbladder epithelium and with the possibility that ET-1 may modulate hydroelectrolytic transport in this epithelium. We herein demonstrate that human gallbladder epithelium displays ET synthesis and ET receptors and that ET-1 inhibits cAMP-dependent anion secretion via a Gi protein-coupled receptor in this epithelium. This is the first evidence that ET-1 may act locally in the biliary tract as a regulator of bile secretion.

\section{Methods}

Reagents. DME/Ham's F12, Moloney murine leukemia virus reverse transcriptase (RT), and Taq DNA polymerase were purchased from Life Technologies (Cergy Pontoise, France). Bordetella pertussis toxin was obtained from Calbiochem (Meudon, France). ATP, ET-1, forskolin, and secretin were supplied by Sigma (Saint-Quentin Fallavier, France) and ${ }^{125} \mathrm{I}-\mathrm{ET}-1$ (2,200 Ci/mmol) was from NEN Life Science Products (Le Blanc Mesnil, France). ET-1 was dissolved in 1\% acetic acid before use. The final concentration of acetic acid never exceeded $0.01 \%$.

Gallbladder preparations. Human gallbladders were obtained by cholecystectomy performed during partial hepatectomy, cephalic duodenal pancreatectomy, and during liver transplantation from the donor. Immediately after cholecystectomy, the gallbladder mucosa was rinsed with DME/Ham's F12 at $4^{\circ} \mathrm{C}$ and examined to verify the absence of macroscopic abnormality.

Cell isolation. Freshly isolated gallbladder epithelial cells were prepared as described previously (7). The mucosa was incubated with a solution of $2.5 \mathrm{mM}$ EDTA and $240 \mathrm{mM} \mathrm{NaCl}(\mathrm{pH} \mathrm{7.4)}$ ) for $45 \mathrm{~min}$ at $4^{\circ} \mathrm{C}$. Epithelial cells were $>98 \%$ pure as assessed by cytokeratin immunolabeling with KL1 antibody (Immunotech, Marseille, France) and cell viability exceeded $90 \%$ as tested by erythrosine exclusion (18).

$R T$ - $P C R$. Freshly isolated gallbladder epithelial cells were homogenized in RNABle lysis solution (Eurobio, Les Ulis, France). Total RNA was extracted according to Chomczynski and Sacchi's method (19).

$1 \mu \mathrm{g}$ of total RNA was denatured by heating at $72^{\circ} \mathrm{C}$ for $10 \mathrm{~min}$ and then incubated in $25 \mu \mathrm{l}$ of a reaction buffer $(50 \mathrm{mM}$ Tris- $\mathrm{HCl}[\mathrm{pH}$ 8.3], $3 \mathrm{mM} \mathrm{MgCl}{ }_{2}$ and $75 \mathrm{mM} \mathrm{KCl}$ ) containing $10 \mathrm{mM}$ 1,4-DTT, 600 $\mu \mathrm{M}$ of deoxynucleoside triphosphate mixture, $2 \mathrm{U} / \mu \mathrm{l}$ of ribonuclease inhibitor, $10 \mu \mathrm{M}$ random hexamers (Pharmacia Biotech, Orsay, France), and $30 \mathrm{U} / \mu \mathrm{l}$ of Moloney murine leukemia virus RT. Reverse transcription was allowed to proceed for $1 \mathrm{~h}$ at $37^{\circ} \mathrm{C}$.

The sequences of oligonucleotide primers used to amplify human preproET-1-, preproET-2-, and preproET-3-specific cDNA fragments of 442,232 , and $479 \mathrm{bp}$, respectively, were designed previously (20) to localize in separate exons and in the least homologous cDNA sequences. Based on the published sequences of human $\mathrm{ET}_{\mathrm{A}}$ and $\mathrm{ET}_{\mathrm{B}}$ receptor cDNAs $(14,15)$ we selected the following primers according to similar criteria: 5' ATC ACC GTC CTC AAC CTC TG 3' (sense) and 5' AGG GCA TAC AGA AAT AGA AC 3' (antisense) that generate a 292-bp product (nucleotides 511-802) of $\mathrm{ET}_{\mathrm{A}}$ receptor cDNA and 5' TCT CTG TGG TTC TGG CTG TC 3' (sense) and 5' CCG TCT CTG CTT TAG GTG AT 3' (antisense) that generate a 275-bp product (nucleotides 683-957) of $\mathrm{ET}_{\mathrm{B}}$ receptor cDNA. Primers of human $\beta$-actin and glyceraldehyde-3-phosphate dehydrogenase (G3PDH) cDNAs used as internal standards were previously designed to amplify cDNA fragments of 644 and $195 \mathrm{bp}$, respectively $(21,22)$. Amplification of cDNA fragments was accomplished using a thermocycler (Perkin-Elmer Cetus; Norwalk, CT) by adding $2.5 \mu \mathrm{l}$ of cDNA to a final volume of $25 \mu \mathrm{l}$ of PCR buffer $(20 \mathrm{mM}$ Tris- $\mathrm{HCl}[\mathrm{pH}$ $8.4]$ and $50 \mathrm{mM} \mathrm{KCl}$ ) containing $1.5-3.5 \mathrm{mM} \mathrm{MgCl}_{2}, 0.1 \mathrm{mM}$ of deoxynucleoside triphosphate mixture, and $0.05 \mathrm{U} / \mu \mathrm{l}$ of $\mathrm{Taq}$ DNA polymerase. To coamplify each preproET with $\beta$-actin cDNA fragments, the reaction was carried out in the presence of 0.5 and $0.06 \mu \mathrm{M}$ of preproET and $\beta$-actin primers, respectively. Because the $\beta$-actindesigned primers were not suitable for coamplification with ET receptors, we chose G3PDH primers instead. The reaction was carried out in the presence of 0.5 and $0.032 \mu \mathrm{M}$ of ET receptor and G3PDH primers, respectively. The thermal conditions of amplification were those of stepdown PCR (23). After an initial 5-min denaturation at $95^{\circ} \mathrm{C}$, the cycling program consisted of $(a)$ a 2-min denaturation at $92^{\circ} \mathrm{C},(b)$ a 1 -min annealing, initially at $10^{\circ} \mathrm{C}$ above the optimal temperature, following a decrease of $2^{\circ} \mathrm{C}$ every two cycles down to the optimal temperature, and (c) a 2-min extension at $72^{\circ} \mathrm{C}$. The following optimal annealing temperatures were determined in preliminary experiments: preproET- $1,54^{\circ} \mathrm{C}$; preproET-2, $64^{\circ} \mathrm{C}$; preproET-3, $59^{\circ} \mathrm{C} ; \mathrm{ET}_{\mathrm{A}}$ and $\mathrm{ET}_{\mathrm{B}}$ receptors, $59^{\circ} \mathrm{C}$. During $\mathrm{PCR}$, samples were withdrawn at regular intervals between 20 and 34 cycles, and subjected to Southern blotting to provide semiquantitative analysis of mRNA, as described previously (24). The compatibility of primer pairs in the coamplification experiments was demonstrated by the fact that identical results were obtained when amplification of preproETs was carried out with or without $\beta$-actin and that of ET receptors with or without G3PDH-specific sequences.

The authenticity of all PCR products was verified by hybridization with an internal oligonucleotide positioned between the primer pairs. Oligonucleotide probes of preproET- and $\beta$-actin-amplified fragments were defined previously $(20,21)$, and those corresponding to nucleotides 567-591 of $\mathrm{ET}_{\mathrm{A}}$ receptor, 741-764 of $\mathrm{ET}_{\mathrm{B}}$ receptor, and $470-499$ of G3PDH were designed according to published cDNA sequences $(14,15,25)$. The RT-PCR products were separated by electrophoresis, transferred to Hybond $\mathrm{N}^{+}$membranes, and hybridized with preproET or ET receptor $\left[\gamma^{-32} \mathrm{P}\right] \mathrm{ATP}-$ labeled probe, as described (21). The membranes were washed and subjected to another hybridization with the internal standard $(\beta$-actin or G3PDH) $[\gamma$ $\left.{ }^{32} \mathrm{P}\right]$ ATP-labeled probe according to the same protocol (21). Southern blots were processed for autoradiography and hybridization signals were quantified by scanning densitometry (Arcus II, AGFA).

ET assays. Immunoreactive ET was measured in freshly isolated gallbladder epithelial cells by RIA, as described (26). The reactivity of the antibody used in the RIA for proET-1, ET-2, and ET-3 was $0.46,475$, and $78 \%$, respectively, compared to that for mature ET-1. The specificity of the antibody was assessed by a cross-reactivity $<0.000 \%$ with unrelated peptides (angiotensin I, angiotensin II, cholecystokinin, substance $\mathrm{P}$, and calcitonin gene-related peptide). The method sensitivity was $0.25 \mathrm{pg}$ per tube, and intra- and interassay reproducibility was 6.1 and $15 \%$, respectively.

The characterization of individual ET isotypes was achieved by a reverse-phase chromatography technique. Peptidic extracts were applied to a PepRPC $\mathrm{C}_{2}$ plus $\mathrm{C}_{18}$ column operating in a fast protein liquid chromatographic system (Pharmacia Biotech). Elution was performed at $25^{\circ} \mathrm{C}$ with a methanol linear gradient in $0.01 \mathrm{M}$ ammonium acetate ( $\mathrm{pH}$ 5.8). 1-ml fractions were collected and immunoreactive ET was assayed in each fraction by the RIA described above. The results were compared with those obtained with ET-1, ET-2, and ET-3 standards.

Binding of ${ }^{125}$ I-ET-1 to gallbladder epithelial cells. Binding experiments were conducted on isolated gallbladder epithelial cells, as described (27). Freshly isolated cells $\left(0.8-1.2 \times 10^{6}\right.$ cells $\left./ \mathrm{ml}\right)$ were incubated in duplicate in $300 \mu \mathrm{l}$ of $\mathrm{KRB}(\mathrm{pH} 7.4)$ containing $20 \mathrm{mM}$ Hepes, $1 \%$ (wt/vol) BSA, $300 \mu \mathrm{g} / \mathrm{ml}$ bacitracin, and ${ }^{125} \mathrm{I}$-ET-1 at concentrations of $40 \mathrm{pM}$ in the time course and competition experiments or of $12.5-800 \mathrm{pM}$ in the saturation experiments. The cells were incubated at $25^{\circ} \mathrm{C}$ under continuous agitation for the selected times. Nonspecific binding of ${ }^{125} \mathrm{I}$-ET- 1 was determined by adding $1 \mu \mathrm{M}$ of native ET-1, and competition experiments were performed in the 
presence of increasing concentrations $\left(10^{-12}-10^{-6} \mathrm{M}\right)$ of native ET-1 or ET-3. The assay was stopped by the addition of $800 \mu \mathrm{l}$ of ice-cold binding buffer. The cells were then separated by filtering through Whatman GF/C filters saturated with $50 \mathrm{mg} / \mathrm{ml} \mathrm{BSA}$, and washed with $9 \mathrm{ml}$ of ice-cold binding buffer. The radioactivity keeping on the filter was counted in a gamma counter. All results were expressed as specific binding and were reported to cell protein that was assessed by Bradford's method (28). Data from saturation and competition experiments were analyzed using the LIGAND program (ElsevierBIOSOFT, Cambridge, UK).

Transepithelial electrical recordings. Preparations of gallbladder mucosa were dissected from the underlying muscular layer and adventitia and were mounted in Ussing-type chambers within $6 \mathrm{~h}$ after cholecystectomy. They were bathed with KRB and gassed with $95 \%$ $\mathrm{O}_{2}-5 \% \mathrm{CO}_{2}$. KRB solution was composed of $120 \mathrm{mM} \mathrm{NaCl}, 0.7 \mathrm{mM}$ $\mathrm{Na}_{2} \mathrm{HPO}_{4}, 1.5 \mathrm{mM} \mathrm{NaH} \mathrm{PO}_{4}, 2 \mathrm{mM} \mathrm{CaCl}, 0.5 \mathrm{mM} \mathrm{MgCl}_{2}, 0.45 \mathrm{mM}$ $\mathrm{KCl}, 15 \mathrm{mM} \mathrm{NaHCO}_{3}$, and $1 \mathrm{mM}$ glucose (pH 7.3). In ion substitution experiments, $\mathrm{Cl}^{-}$and/or $\mathrm{HCO}_{3}{ }^{-}$were replaced with gluconate and the preparations were bathed in low $\mathrm{Cl}^{-}$and/or $\mathrm{HCO}_{3}{ }^{-} / \mathrm{CO}_{2}$-free solutions for 30-60 min before being mounted in Ussing-type chambers. The low $\mathrm{Cl}^{-}$solution contained $4-6 \mathrm{mM} \mathrm{Cl}^{-}$. The $\mathrm{HCO}_{3}{ }^{-} / \mathrm{CO}_{2}$-free Ringer solution was gassed with $100 \% \mathrm{O}_{2}$. The experiments in Ussing-type chambers were conducted at $37^{\circ} \mathrm{C}$. The short-circuit current (Isc) was monitored continuously using a DVC1000 voltage clamp (World Precision Instruments, Aston, UK); the potential difference was measured every 5-10 min. Voltage-sensing electrodes consisted of $3 \mathrm{M} \mathrm{KCl-agar} \mathrm{bridges;} \mathrm{the} \mathrm{reference} \mathrm{electrode} \mathrm{was}$ placed at the basolateral side. Current-passing bridges consisted of KRB-agar bridges. Transepithelial resistance was determined by clamping the potential difference to $+10 \mathrm{mV}$ or $+5 \mathrm{mV}$ at 25 -s intervals and recording the deflection in Isc, and applying Ohm's law. Tissue samples were allowed to equilibrate until stabilization of bioelectric variables, which required $\sim 20-30 \mathrm{~min}$. Basal bioelectric activity was recorded for $10 \mathrm{~min}$. Either ET-1 $\left(10^{-7} \mathrm{M}\right)$ or vehicle was then added simultaneously to samples issued from the same preparations, $10-15 \mathrm{~min}$ before forskolin $\left(10^{-5} \mathrm{M}\right)$, secretin $\left(10^{-7} \mathrm{M}\right)$, or ATP $\left(10^{-4}\right.$ $\mathrm{M})$. ET-1, forskolin, and secretin were added to the apical and basolateral baths, while ATP was added to the apical bath only. Bioelectric activity was monitored for $10-15$ min after the addition of ET-1 or vehicle and after that of forskolin, secretin, or ATP. Changes in transepithelial resistance and Isc were calculated as the variations between the values measured immediately before the addition of reagents and the values corresponding to the plateau phase after the addition of forskolin or secretin and corresponding to the maximal change after the addition of ATP.

cAMP assay. Freshly isolated gallbladder epithelial cells (0.8$1.2 \times 10^{6}$ cells $/ \mathrm{ml}$ ) were suspended in DME/Ham's F12 containing $0.2 \%(\mathrm{wt} / \mathrm{vol}) \mathrm{BSA}$. ET- $1\left(10^{-7} \mathrm{M}\right)$ or vehicle was added to duplicate $300-\mu \mathrm{l}$ aliquots of the same cell suspension $10 \mathrm{~min}$ before forskolin $\left(10^{-5} \mathrm{M}\right)$ or secretin $\left(10^{-7} \mathrm{M}\right)$. In some experiments, the samples exposed to ET-1 were preincubated with $B$. pertussis toxin $(100 \mathrm{ng} / \mathrm{ml})$ for $4 \mathrm{~h}$ at $37^{\circ} \mathrm{C}$. The cells were then stimulated by forskolin or secretin for $10 \mathrm{~min}$ at $37^{\circ} \mathrm{C}$, and transferred on ice before $40 \mu \mathrm{M}$ digitonine and $0.1 \mu \mathrm{M}$ 3-isobutyl-1-methylxanthine in DME/Ham's F12 were added. The samples were centrifuged at $1,300 \mathrm{~g}$ for $7 \mathrm{~min}$ at $4^{\circ} \mathrm{C}$. cAMP was assayed in the supernatant by a commercial RIA (NEN Life Science Products). The protein content of cell suspension aliquots was determined by the method of Bradford (28).

Statistical analysis. Results are expressed as the means \pm SEM. Comparisons were made using an unpaired or paired Student's $t$ test as appropriate. $P<0.05$ was considered as significant.

\section{Results}

Expression of ET precursor genes in gallbladder epithelial cells. We explored the potential of gallbladder epithelial cells to express the different ET precursor genes, by using RT-PCR. cycle number
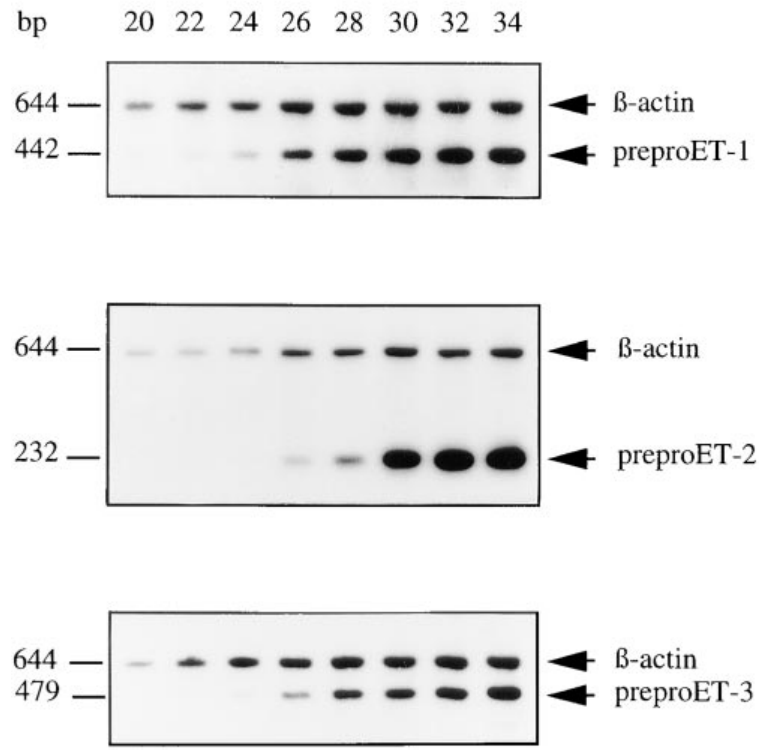

Figure 1. Relative abundance of preproET-1, -2 , and -3 mRNAs detected by RT-PCR in isolated gallbladder epithelial cells. Total RNA $(1 \mu \mathrm{g})$ prepared from four separate isolates of gallbladder epithelial cells was reverse-transcribed. Samples of cDNA were subjected to PCR amplifications for preproET-1, -2, or -3 , each one combined with $\beta$-actin coamplification. To monitor the kinetics of product formation, aliquots were withdrawn at indicated PCR cycles and analyzed by Southern blotting. The autoradiograms are representative of results that were reproduced by the analysis of three additional cell preparations.

All three preproET-1, -2 , and -3 mRNA species were detected in freshly isolated cells derived from four different gallbladders (Fig. 1). To compare the levels of expression of the three ET precursor genes, the relative abundance of preproET-1, -2, and -3 transcripts was estimated by monitoring the kinetics of amplification of cDNA during PCR. The cDNA samples obtained from individual cell preparations were subjected to separate amplifications for preproET-1, -2 , or -3 , each one combined with $\beta$-actin coamplification. Aliquots taken during PCR were analyzed for product formation by Southern blots (Fig. 1) and the ratios of preproET to $\beta$-actin signal intensities were determined at various cycle numbers. The preproET-1/ $\beta$ actin ratio was constantly higher than those of preproET-2 and preproET-3 within the exponential phase of amplification, in the range of 20-26 cycles, suggesting that preproET-1 mRNA is more abundant than preproET-2 and preproET-3 mRNAs in the gallbladder epithelium. However, the difference did not reach statistical significance (not shown). The occurrence of ET-1 biosynthesis in the gallbladder epithelial cells was documented by the detection of immunoreactive ET $(42 \pm 10 \mathrm{pg} / \mathrm{mg}$ protein) in freshly isolated cells and the demonstration by reverse-phase chromatography that $>90 \%$ of ET derived from the cells consisted of ET-1 (Fig. 2). By contrast, no significant amounts of ET-2 or ET-3 were identified, despite the presence of precursor mRNAs.

Expression of ET receptor genes in gallbladder epithelial cells. Because ET-1 has been shown to function as an autocrine factor in other cell types, we tested the hypothesis that 


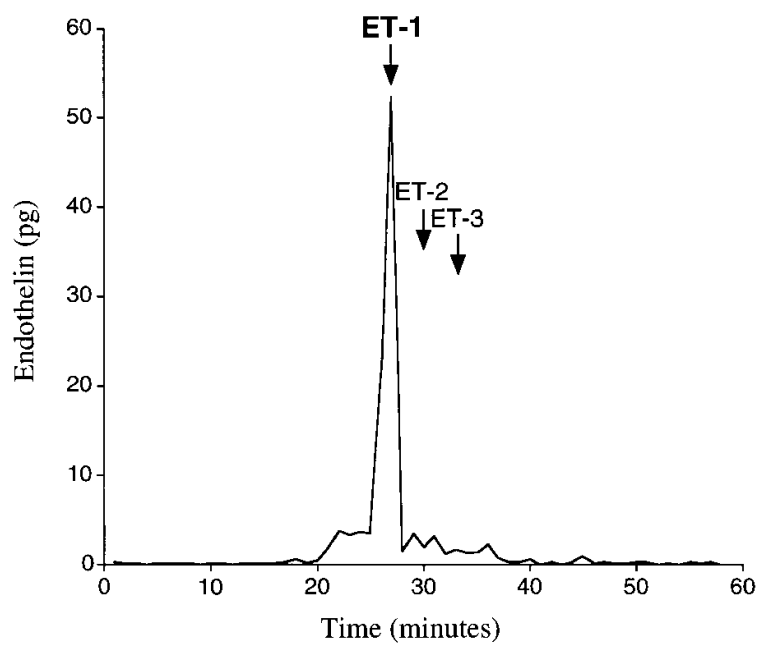

Figure 2. Separation of ET isopeptides in freshly isolated gallbladder epithelial cells by reverse phase chromatography. Peptidic extracts were applied to a PepRPC ${ }^{2} \mathrm{C}$ plus ${ }^{18} \mathrm{C}$ column operating in a fast protein liquid chromatographic system. 1-ml fractions were collected and immunoreactive ET was assayed in each fraction by RIA as described in Methods. The elution times of ET-1, -2 , and -3 standards are indicated.

gallbladder epithelial cells also display ET receptor expression. Both $\mathrm{ET}_{\mathrm{A}}$ and $\mathrm{ET}_{\mathrm{B}}$ receptor mRNAs were detected by RT-PCR in freshly isolated gallbladder epithelial cells (Fig. 3). We used the same approach to compare the levels of expression of ET receptor genes, as we did to compare those of ET precursor genes. The same RT products that were amplified for preproET were subjected to separate amplifications for $\mathrm{ET}_{\mathrm{A}}$ and $\mathrm{ET}_{\mathrm{B}}$, each one combined with G3PDH coamplification. When increasing the number of cycles, the $\mathrm{ET}_{\mathrm{B}}$ receptor signal became detectable at 28 cycles and markedly increased thereafter, until reaching the same intensity as that of G3PDH at 34 cycles. By contrast, the $\mathrm{ET}_{\mathrm{A}}$ receptor signal became detectable at 30 cycles and remained notably weaker than that of

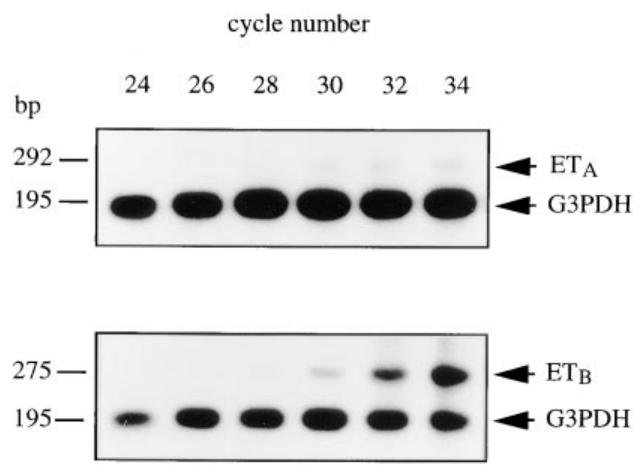

Figure 3. Relative abundance of $\mathrm{ET}_{\mathrm{A}}$ and $\mathrm{ET}_{\mathrm{B}}$ receptor mRNAs detected by RT-PCR in isolated gallbladder epithelial cells. The same cDNA samples in Fig. 1 were subjected to PCR amplifications for $\mathrm{ET}_{\mathrm{A}}$ or $\mathrm{ET}_{\mathrm{B}}$ receptor, each one combined with G3PDH coamplification. To monitor the kinetics of product formation, aliquots were withdrawn at indicated PCR cycles and analyzed by Southern blotting. The autoradiograms are representative of results that were reproduced by the analysis of three additional cell preparations.
G3PDH until 34 cycles (Fig. 3), providing evidence that the level of $\mathrm{ET}_{\mathrm{B}}$ expression is much higher than that of $\mathrm{ET}_{\mathrm{A}}$ in normal human gallbladder epithelium.

Binding sites for ET-1 to gallbladder epithelial cells. The presence of ET receptors on gallbladder epithelial cells was confirmed by binding experiments. Specific binding of ${ }^{125}$ I-ET-1 to freshly isolated gallbladder epithelial cells was saturable and showed high affinity (Fig. 4). Scatchard analysis (Fig. 4, inset) revealed the presence of a single class of binding sites, with an apparent $K_{\mathrm{d}}$ of $536 \pm 85 \mathrm{pM}$ and a density of $25 \pm 10 \mathrm{fmol} / \mathrm{mg}$ protein, which may represent an underestimation of maximal binding capacity $\left(B_{\max }\right)$, since it was determined at $60 \mathrm{~min}$, shortly before maximal steady-state binding was completed according to time course experiments (not shown). The majority of detected receptors bound ET-1 and ET-3 with similar affinities, as shown in Fig. 5. The binding of ${ }^{125}$ I-ET-1 was inhibited in a dose-dependent manner by ET- 1 or ET-3 with mean $\mathrm{IC}_{50}$ values of 1,400 and $2,700 \mathrm{pM}$, respectively. These results, combined with the mRNA data, clearly demonstrated the preponderance of $\mathrm{ET}_{\mathrm{B}}$ over $\mathrm{ET}_{\mathrm{A}}$ receptors in gallbladder epithelial cells.

Effect of ET-1 on ion transport across the gallbladder epithelium. To determine the effect of ET-1 on ion transport across the gallbladder epithelium, the bioelectric activity of intact human gallbladder mucosa was recorded in Ussing-type chambers. The baseline potential difference, Isc, and resistance were of $-2.2 \pm 0.3 \mathrm{mV}, 40.7 \pm 7.8 \mathrm{~mA} / \mathrm{cm}^{2}$, and $66.5 \pm 9.6$ $\Omega \cdot \mathrm{cm}^{2}$, respectively $(n=14)$. Significant increases in Isc were induced by forskolin, secretin, and extracellular ATP, which are known as potent ion secretagogues in the gallbladder epithelium. As shown in Table I and in additional studies (Chinet, T., et al., manuscript submitted for publication) forskolin and ATP-induced changes in Isc were impeded when the bathing solutions were depleted in $\mathrm{Cl}^{-}$and $\mathrm{HCO}_{3}{ }^{-}$. These results indicate that the changes in Isc induced by these agonists are accounted for by the stimulation of active anion secretion across

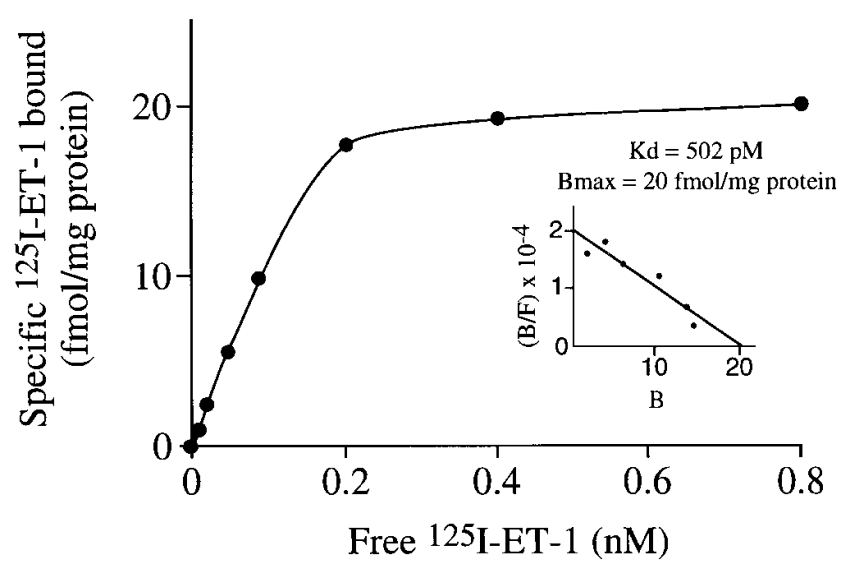

Figure 4. Specific binding of ${ }^{125}$ I-ET-1 to gallbladder epithelial cells. Freshly isolated gallbladder epithelial cells were incubated in suspension with increasing concentrations of ${ }^{125} \mathrm{I}-\mathrm{ET}-1$ for $60 \mathrm{~min}$ at $25^{\circ} \mathrm{C}$. Nonspecific binding of ${ }^{125}$ I-ET- 1 was determined by adding excess native ET-1 $(1 \mu \mathrm{M})$ and was subtracted from total binding. Specific binding was reported to cell protein. (Inset) Scatchard plot. B, bound; $F$, free. Results represent duplicate data from a typical experiment that was repeated twice. 


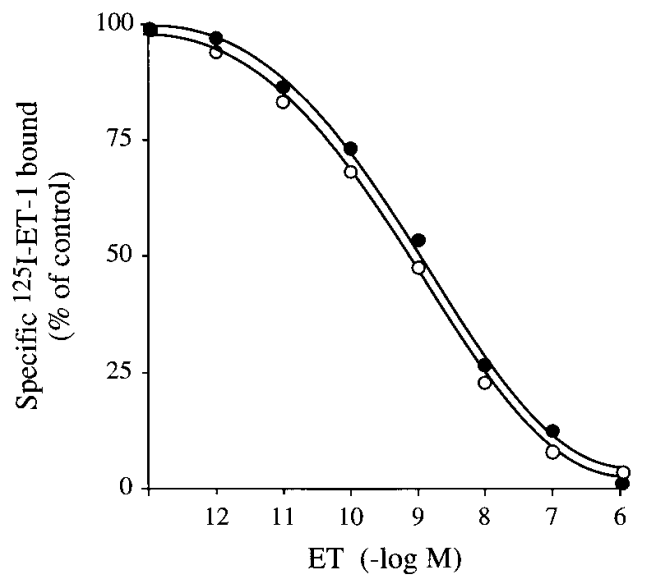

Figure 5. Inhibition of ${ }^{125}$ I-ET-1 binding to gallbladder epithelial cells by native ET-1 and -3 . Freshly isolated gallbladder epithelial cells were incubated in suspension with ${ }^{125}$ I-ET-1 $(40 \mathrm{pM})$ and increasing concentrations of native ET-1 (open circles) or -3 (closed circles), for $60 \mathrm{~min}$ at $25^{\circ} \mathrm{C}$. Specific binding was expressed as a percentage of control determined in the absence of ET. The results represent duplicate data from a typical experiment that was repeated twice.

the gallbladder epithelium. By exposing the gallbladder mucosa sequentially to ET-1 and to forskolin, secretin, or ATP, we found that the addition of ET-1, while causing no significant change in the baseline bioelectric activity, significantly reduced the forskolin-induced increase in Isc by $70 \pm 4 \%(P<$ 0.05 ) and completely inhibited the response to secretin (Fig. 6, $A$ and $B)$. By contrast, ET-1 did not significantly affect the electrogenic response to ATP (Fig. 6, $A$ and $B$ ). Since forskolin and secretin are effectors of adenylate cyclase, these results indicated that ET-1 exerts an inhibitory effect on cAMPdependent anion secretion in the gallbladder epithelium.

Effect of ET-1 on cAMP production. We next tested the effect of ET-1 on the production of intracellular cAMP in this epithelium. Intracellular cAMP levels were determined in freshly isolated gallbladder epithelial cells exposed to reagents under experimental conditions similar to those used for Isc measurements across intact gallbladder epithelium. Forskolin and secretin induced increases in cAMP from basal levels of $9.7 \pm 4.5$ to $346.0 \pm 100.0(n=7)$ and $21.5 \pm 6.3 \mathrm{pmol} / \mathrm{mg}$ protein $(n=5)$, respectively, while ET-1 alone had no effect $(12.0 \pm 4.5, \mathrm{NS})$. However, ET-1 reduced the increases in intra- cellular cAMP concentrations induced by forskolin and secretin by $42 \pm 1 \%$ and $37 \pm 1 \%$, respectively (Fig. 7). Because ET receptors belong to the $\mathrm{G}$ protein-coupled receptor superfamily, the effect of $B$. pertussis toxin was investigated. We found that the inhibitory effect of ET-1 on forskolin- and secretininduced cAMP production was totally abolished by pertussis toxin (Fig. 7), indicating that ET-1 inhibits the stimulation of adenylate cyclase via a pertussis toxin-sensitive Gi protein.

\section{Discussion}

This study provides the first evidence for the biosynthesis and biological role of ET-1 in the biliary epithelium. We show that human gallbladder-derived biliary epithelial cells display constitutive expression of ET precursor genes and of ET receptors and that ET-1 inhibits cAMP-dependent electrogenic anion secretion in this epithelium, via a pertussis toxin-sensitive pathway.

We reported previously that human gallbladder epithelial cells in primary culture release high amounts of immunoreactive ET peptide in the supernatant (17). We herein confirm the ability of gallbladder epithelial cells to synthesize ET by showing the presence of preproET mRNA in these cells. In addition, the fact that preproET mRNA was identified in freshly isolated cells indicates that ET biosynthesis also occurs in vivo. The three preproET-1, -2 , and -3 mRNAs were detected in the gallbladder epithelium, as described thus far only in the intestine (29). By using a semiquantitative RT-PCR method, we found that preproET-1 mRNA tended to be more abundant than preproET-2 and -3 mRNA species in the gallbladder epithelial cells, although the difference did not reach statistical significance. In addition, ET-1 isopeptide was identified by reverse-phase chromatography in the freshly isolated cells, and in the supernatant of cultured cells, as reported previously (17). The fact that neither ET-2 nor - 3 isopeptides could be detected despite the presence of preproET-2 and -3 mRNAs could be due to the fact that the quantity of transcripts is not sufficient to give rise to significant amounts of peptides. Another possibility is that despite significant synthesis of transcripts, the posttranscriptional steps, including processing of the prepropeptides, are disrupted in gallbladder epithelial cells, as postulated before for preproET-2 alternatively spliced mRNA variants (30). Proteolytic processing of preproETs gives rise to proETs that are converted to the mature peptides by ET converting enzymes. The presence of an ET converting enzyme that converts proET-1 but not -2 or -3 has been reported in different cells including renal epithelial cell lines

Table I. Effect of Anion Depletion on Basal and Stimulated ISC Across Human Gallbladder Mucosa

\begin{tabular}{llcc}
\hline & Baseline Isc & Forskolin-induced $\Delta$ Isc & ATP-induced $\Delta$ Isc \\
\hline Regular KRB $(n=14)$ & $40.7 \pm 7.8$ & $8.0 \pm 1.4^{\ddagger}$ & $10.3 \pm 1.8^{\ddagger}$ \\
$\mathrm{HCO}_{3}-\mathrm{CO}_{2}$-free KRB $(n=6)$ & $46.9 \pm 8.3$ & $8.1 \pm 1.9^{\ddagger}$ & $10.0 \pm 3.4^{\ddagger}$ \\
Low $\mathrm{Cl}^{-} \mathrm{KRB}(n=6)$ & $28.0 \pm 8.7$ & $3.9 \pm 0.8^{\ddagger}$ & $12.1 \pm 6.3^{\ddagger}$ \\
Low $\mathrm{Cl}^{-}$and $\mathrm{HCO}_{3}^{-} / \mathrm{CO}_{2}$-free KRB $(n=6)$ & $16.2 \pm 3.7^{*}$ & $1.1 \pm 0.5^{*}$ & $2.8^{*} \pm 0.8^{*}$
\end{tabular}

Baseline Isc and changes in Isc ( $\Delta \mathrm{Isc}$ ) induced by forskolin or extracellular ATP were measured in preparations of human gallbladder mucosa bathed in regular KRB and in KRB depleted in chloride and/or bicarbonate. The results are expressed in $\mu \mathrm{A} / \mathrm{cm}^{2}$ and represent mean \pm SEM. $*$ Significant difference $(P<0.05)$ in comparison with the values obtained in regular KRB. ${ }^{\ddagger}$ Significant change $(P<0.05)$ after the addition of forskolin or extracellular ATP, in comparison with baseline values. 

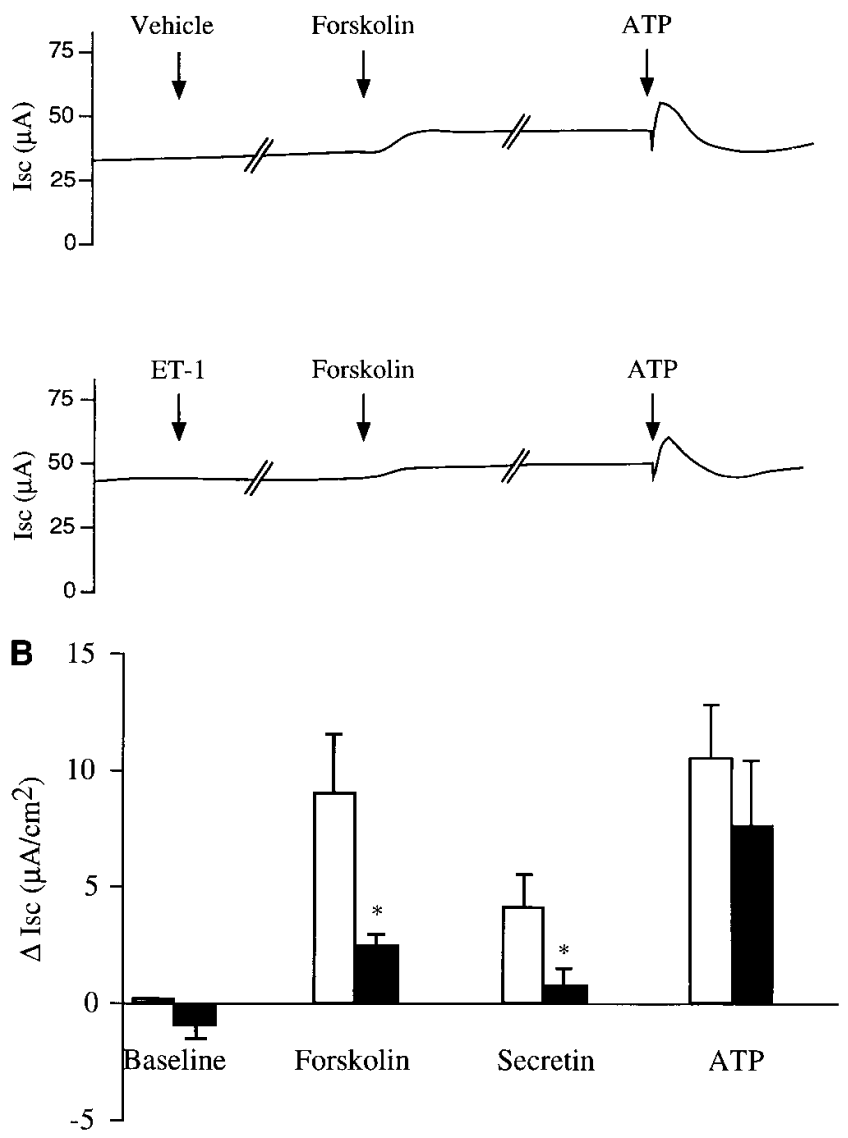

Figure 6. Effects of ET-1 on basal and stimulated Isc across human gallbladder mucosa. Two samples issued from the same preparations were mounted simultaneously in Ussing-type chambers. Vehicle or ET-1 $\left(10^{-7} \mathrm{M}\right)$, forskolin $\left(10^{-5} \mathrm{M}\right)$ or secretin $\left(10^{-7} \mathrm{M}\right)$ and ATP $\left(10^{-4} \mathrm{M}\right)$ were added sequentially. Bioelectric activity was monitored for 10-15 min after the addition of ET-1 or vehicle and after that of forskolin, secretin, or ATP. $(A)$ A representative tracing of the Isc across human gallbladder mucosa showing the inhibitory effect of ET-1 on forskolin-induced change in Isc and no effect on the response to ATP. $(B)$ Changes in Isc $(\Delta I s c)$ in the presence of vehicle (open bars) or ET-1 (closed bars) were calculated as the variations between the values measured immediately before the addition of reagents and the values corresponding to the plateau or maximal change after the addition of reagents. Results are expressed as mean \pm SEM of at least four separate experiments. $* P<0.05$ in comparison with the corresponding controls.

(31), and the two ET converting enzymes, ECE-1 and -2 that were recently cloned, convert proET-1 more efficiently than proET-2 or $-3(32,33)$. It has also been shown that different organs may exhibit distinct ET converting enzyme activity with regard to isopeptide selectivity, as illustrated by the identification of ET converting enzyme activities with similar affinities for proET-1 and -2 in the kidney, but with lower affinity for proET-2 than for proET-1 in the lung (34). Therefore, one can speculate that ET converting enzyme with preferential cleavage of proET-1 is expressed in the gallbladder epithelium.

The demonstration that gallbladder epithelial cells both produce ET-1 and possess specific ET receptors suggests that ET-1 could participate in the regulation of biliary epithelial cell function. This assumption is supported by the demonstration that ET-1 inhibits cAMP-dependent electrogenic ion transport across the gallbladder epithelium. cAMP is a major regulator of fluid transport in the biliary epithelium and mediates the stimulating effects of secretin and vasoactive intestinal polypeptide in the intrahepatic and gallbladder biliary epithelial cells $(7,8)$. It has been established that intracellular cAMP activates cystic fibrosis transmembrane conductance regulator (CFTR), the cystic fibrosis gene product, which functions as a cAMP-regulated chloride channel in the apical membrane of biliary epithelial cells $(35,36)$. The mechanisms of fluid and bicarbonate secretion associated with the activation of CFTR are still speculative. The transepithelial extrusion of chloride ions generates a negative intraluminal potential that triggers passive secretion of sodium and water, resulting in fluid secretion (37). Bicarbonate secretion occurs via the chloride/bicarbonate anion exchanger localized in the apical membrane of intrahepatic and gallbladder biliary epithelial cells (38), and probably also via direct extrusion through anion channels including CFTR itself (39). Stimulation of anion secretion by a cAMP-dependent pathway across intact gallbladder mucosa was documented in this study, by the fact that forskolin induced a significant increase in Isc in Ussing-type chamber and that this increase was significantly reduced by the depletion of bathing solutions in chloride and bicarbonate. Furthermore, the response to forskolin was significantly reduced by the addition of diphenylamine carboxylic acid, a CFTR channel inhibitor, and was abolished in preparations of gallbladder mucosa from cystic fibrosis patients (Chinet, T., et al., manuscript submitted for publication), in keeping with the role of CFTR in
A

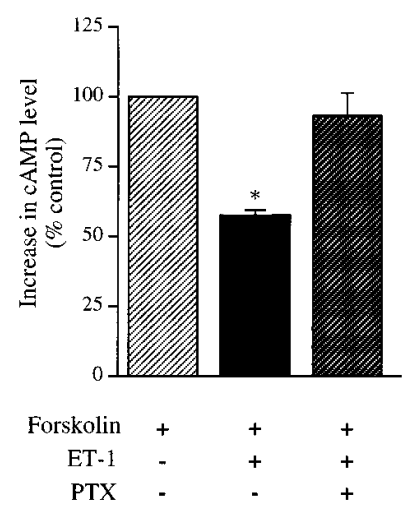

B

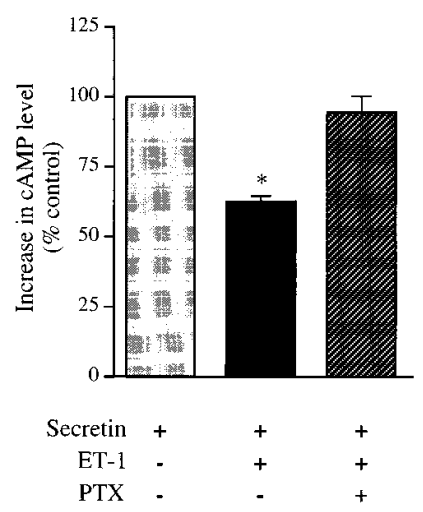

Figure 7. Inhibitory effect of ET-1 on forskolin- and secretin-induced cAMP production via a pertussis toxin-sensitive pathway. Freshly isolated gallbladder epithelial cells were incubated in the presence or absence of $100 \mathrm{ng} / \mathrm{ml}$ of $B$. pertussis toxin $(P T X)$, with or without ET-1 $\left(10^{-7} \mathrm{M}\right)$. The cells were then stimulated by $(A)$ forskolin $\left(10^{-5} \mathrm{M}\right)$ or $(B)$ secretin $\left(10^{-7} \mathrm{M}\right)$ before the intracellular levels of cAMP were determined as described in Methods. The basal levels of cAMP were also determined in untreated cells. The results are expressed as a percentage of controls defined by the accumulation of intracellular cAMP elicited by forskolin or secretin alone. Data represent mean \pm SEM of at least four separate experiments performed in triplicate. ${ }^{*} P<0.05$ in comparison with the corresponding controls. 
biliary cAMP-dependent anion secretion. The finding that ET-1 exerts a potent inhibitory effect on electrogenic ion transport due to the activation of a cAMP-dependent pathway by forskolin and secretin suggests that ET-1 may interact with the activation of CFTR by cAMP in the gallbladder epithelium. This possibility was supported by the fact that ET-1 had no significant effect on electrogenic ion transport induced by extracellular ATP, which is known to stimulate chloride conductance in biliary epithelial cells through CFTR-independent chloride channels (9).

More direct evidence for the regulation of cAMP level by ET-1 in the gallbladder epithelium was provided by the fact that ET-1 reduced the accumulation of intracellular cAMP elicited by forskolin and secretin, which are both effectors of adenylate cyclase. However, apparently anion secretion was not proportional to the cAMP levels induced by the different effectors. A possible explanation is that the measurements of cAMP that were carried out in isolated cells may not strictly reflect the levels induced in the intact tissue. We cannot exclude, in particular, that the receptors on the plasma membrane are partly altered by cell isolation, which would result in the undervaluation of the cAMP levels in response to secretin, but not to forskolin, which directly activates adenylate cyclase. It is also possible that, even though cAMP modulation plays a major role in the inhibition of ion transport by ET-1, additional signaling pathways are involved.

The effect of ET-1 on cAMP increase in response to forskolin and to secretin was not influenced by the addition of 3-isobutyl-1-methyl-xanthine, an inhibitor of dibutyryl phosphodiesterase (not shown), but was totally suppressed by pertussis toxin treatment. Pertussis toxin is known to induce adenosine diphosphate ribosylation of $\mathrm{Gi}$ and Go guanine nucleotide-binding proteins and to inhibit their functions. Therefore, we concluded from these results that ET-1 inhibits the activity of adenylate cyclase, mainly through pertussis toxin-sensitive Gi protein. This signaling mechanism is likely to be mediated by $\mathrm{ET}_{\mathrm{B}}$ receptors, which far outnumber $\mathrm{ET}_{\mathrm{A}}$ receptors in the gallbladder epithelium as shown by mRNA data and binding experiments. The dissociation constant of $\mathrm{ET}_{\mathrm{B}}$ receptor in the gallbladder epithelial cells is in the nanomolar range, as reported previously in other cell types (40). Furthermore, in most expression systems, $\mathrm{ET}_{\mathrm{B}}$ is associated with the inhibition of adenylate cyclase while $\mathrm{ET}_{\mathrm{A}}$ is associated with its stimulation (41). It is unlikely that the activation of $\mathrm{ET}_{\mathrm{A}}$ receptors, which were not detectable by binding experiments, contributed to the effects of ET-1 described above. Nevertheless, $\mathrm{ET}_{\mathrm{A}}$ activation can also lead to the inhibition of adenylate cyclase in specific cell types, as shown in guinea pig ventricular myocytes, where ET-1 acting through $\mathrm{ET}_{\mathrm{A}}$ receptors inhibits chloride conductance by reducing the intracellular cAMP concentration via a pertussis toxin-sensitive mechanism (42).

Ion and fluid secretion across the biliary epithelium plays a fundamental role in preventing the stagnation and subsequent toxic effect of bile salts in the biliary tract, and in assisting the gallbladder to empty upon stimulation by a meal. Our results imply that ET-1, produced by gallbladder and also intrahepatic biliary epithelial cells as suggested by previous work $(17,43)$, acts as an autocrine modulator of biliary epithelial transport. A similar autocrine effect of ET-1 has been implicated in the inhibition of vasopressin-induced water permeability in rat inner medullary collecting ducts via $\mathrm{ET}_{\mathrm{B}}$ receptors and a pertus- sis toxin $\mathrm{G}$ protein/adenylate cyclase inhibition pathway (11). In addition, the property of Gi proteins to maintain a tonic inhibition of different types of anion channels, including CFTR, has been demonstrated previously in airway and biliary epithelial cells $(44,45)$. The hepatobiliary production of ET-1 increases dramatically under pathological conditions such as cholestatic liver injury and has deleterious effects, including roles in fibrogenesis and portal hypertension $(43,46)$. A tonic inhibition of the anion conductance by ET-1 under such circumstances can be expected to counteract the biliary epithelial hypersecretion associated with the typical ductular reaction due to biliary epithelial proliferation (3). This effect of ET-1 added to the impairment of liver blood flow could contribute to the cholestatic effect of ET-1 at a high concentration (47). Validation of this postulate in the intact liver will provide additional rationale for studies of ET receptor antagonists in the therapy of cholestatic liver diseases.

\section{Acknowledgments}

The authors are grateful to Christian Gespach, INSERM U55, Joëlle Masliah, CNRS UPRESA 7079, Didier Pelaprat, INSERM U339, and Claudine Serradeil-Le Gal, SANOFI Recherche, for helpful suggestions, to Yves Chrétien for performing statistical analyses, to Mama Imam-Ghali and Eric Noé for technical assistance, and to Mickael Bouin and Fatima Lakehal for their contribution to the experiments.

This work was supported by grants from Institut National de la Santé et de la Recherche Médicale (INSERM), Association Française de Lutte contre la Mucoviscidose, Association de Lutte contre les Myopathies, Laboratoires Ferring-France, and from Chancellerie des Universités de Paris.

\section{References}

1. Svanvik, J. 1993. Role of gallbladder in modifying hepatic bile composition. In Hepatic Transport and Bile Secretion: Physiology and Pathophysiology. N. Tavaloni and P.D. Berk, editors. Raven Press, Ltd., New York. 607-618.

2. Boyer, J.L. 1996. Bile duct epithelium: frontiers in transport physiology. Am. J. Physiol. 270:G1-G5.

3. Alpini, G., R. Lenzi, L. Sarkosi, and N. Tavoloni. 1988. Biliary physiology in rats with bile ductular cell hyperplasia. Evidence for a secretory function of proliferated bile ductules. J. Clin. Invest. 81:569-578.

4. Nyberg, B., K. Einarsson, and T. Sonnenfeld. 1989. Evidence that vasoactive intestinal peptide induces ductular secretion of bile in humans. Gastroenterology. 96:920-924.

5. Jansson, R., G. Steen, and J. Svanvik. 1978. Effects of intravenous vasoactive intestinal peptide (VIP) on gallbladder function in the cat. Gastroenterology. 75:47-50.

6. Igimi, H., F. Yamamoto, and S.P. Lee. 1992. Gallbladder mucosal function: studies in absorption and secretion in humans and in dog gallbladder epithelium. Am. J. Physiol. 263:G69-G74.

7. Dupont, C., J.-P. Broyart, Y. Broer, B. Chenut, M. Laburthe, and G. Rosselin. 1981. Importance of the vasoactive intestinal peptide receptor in the stimulation of cyclic adenosine $3^{\prime}, 5^{\prime}$-monophosphate in gallbladder epithelial cells of man. J. Clin. Invest. 67:742-752.

8. Kato, A., G.J. Gores, and N.F. LaRusso. 1992. Secretin stimulates exocytosis in isolated bile duct epithelial cells by a cyclic AMP-mediated mechanism. J. Biol. Chem. 267:15523-15529.

9. McGill, J.M., S. Basavappa, A.W. Mangel, G.H. Shimokura, J.P. Middleton, and J.G. Fitz. 1994. Adenosine triphosphate activates ion permeabilities in biliary epithelial cells. Gastroenterology. 107:236-243.

10. Kiyohara, T., M. Okuno, T. Nakanishi, Y. Shinomura, and Y. Matsuzawa. 1993. Effect of endothelin 1 on ion transport in isolated rat colon. Gastroenterology. 104:1328-1336.

11. Kohan, D.E., and A.K. Hughes. 1993. Autocrine role of endothelin in rat IMCD: inhibition of AVP-induced cAMP accumulation. Am. J. Physiol. 265:F126-F129.

12. Markewitz, B.A., D.E. Kohan, and J.R. Michael. 1995. Endothelin-1 synthesis, receptors, and signal transduction in alveolar epithelium: evidence for an autocrine role. Am. J. Physiol. 268:L192-L200.

13. Inoue, A., M. Yanagisawa, S. Kimura, Y. Kasuya, T. Miyauchi, K. Goto, 
and T. Masaki. 1989. The human endothelin family: three structurally and pharmacologically distinct isopeptides predicted by three separate genes. Proc. Natl. Acad. Sci. USA. 86:2863-2867.

14. Hosoda, K., K. Nakao, H. Arai, S. Suga, Y. Ogawa, M. Mukoyama, G. Shirakami, Y. Saito, S. Nakanishi, and H. Imura. 1991. Cloning and expression of human endothelin-1 receptor cDNA. FEBS (Fed. Eur. Biochem. Soc.) Lett. 287:23-26.

15. Ogawa, Y., K. Nakao, H. Arai, O. Nakagawa, K. Hosoda, S.-I. Suga, S. Nakanishi, and H. Imura. 1991. Molecular cloning of a non-isopeptide-selective human endothelin receptor. Biochem. Biophys. Res. Commun. 178:248-255.

16. MacCumber, M.W., C.A. Ross, B.M. Glaser, and S.H. Snyder. 1989. Endothelin: visualization of mRNAs by in situ hybridization provides evidence for local action. Proc. Natl. Acad. Sci. USA. 86:7285-7289.

17. Housset, C., A. Carayon, B. Housset, C. Legendre, L. Hannoun, and R. Poupon. 1993. Endothelin-1 secretion by human gallbladder epithelial cells in primary culture. Lab. Invest. 69:750-755.

18. Krause, A.W., W.W. Carley, and W.W. Webb. 1984. Fluorescent erythrosin $\mathrm{B}$ is preferable to trypan blue as a vital exclusion dye for mammalian cells in monolayer culture. J. Histochem. Cytochem. 32:1084-1090.

19. Chomczynski, P., and N. Sacchi. 1987. Single-step method of RNA isolation by acid guanidinium thiocyanate-phenol-chloroform extraction. Anal. Biochem. 162:156-159.

20. Robert, B., A. Malassiné, C. Bourgeois, T.-M. Mignot, L. Cronier, F. Ferré, and P. Duc-Goiran. 1996. Expression of endothelin precursor genes in human trophoblast in culture. Eur. J. Endocrinol. 134:490-496.

21. Mergey, M., M. Lemnaouar, D. Veissière, M. Perricaudet, D.C. Gruenert, J. Picard, J. Capeau, M.-C. Brahimi-Horn, and A. Paul. 1995. CFTR gene transfer corrects defective glycoconjugate secretion in human CF epithelial tracheal cells. Am. J. Physiol. 269:L855-L864.

22. Narayanan, R., K.G. Lawlor, R.Q.J. Schaapveld, K.R. Cho, B. Vogelstein, P.B.-V. Tran, M.P. Osborne, and N.T. Telang. 1992. Antisense RNA to the putative tumor-suppressor gene DCC transforms Rat-1 fibroblasts. Oncogene. 7:553-561.

23. Hecker, K.H., and K.H. Roux. 1996. High and low annealing temperatures increase both specificity and yield in touchdown and stepdown PCR. BioTechniques. 20:478-485.

24. Noonan, K.E., C. Beck, T.A. Holzmayer, J.E. Chin, J.S. Wunder, IL. Andrulis, A.F. Gazdar, C.L. Willman, B. Griffith, D.D. Von Hoff, et al. 1990. Quantitative analysis of MDR1 (multidrug resistance) gene expression in human tumors by polymerase chain reaction. Proc. Natl. Acad. Sci. USA. 87:71607164.

25. Tokunaga, K., Y. Nakamura, K. Sakata, K. Fujimori, M. Ohkubo, K. Sawada, and S. Sakiyama. 1987. Enhanced expression of a glyceraldehyde3-phosphate dehydrogenase gene in human lung cancers. Cancer Res. 47:56165619.

26. Cacoub, P., R. Dorent, G. Maistre, P. Nataf, A. Carayon, C. Piette, P. Godeau, C. Cabrol, and I. Gandjbakhch. 1993. Endothelin-1 in primary pulmonary hypertension and the Eisenmenger syndrome. Am. J. Cardiol. 71:448-450.

27. Serradeil-Le Gal, C., C. Jouneaux, A. Sanchez-Bueno, D. Raufaste, B. Roche, A.M. Préaux, J.P. Maffrand, P.H. Cobbold, J. Hanoune, and S. Lotersztajn. 1991. Endothelin action in rat liver. Receptors, free $\mathrm{Ca}^{2+}$ oscillations, and activation of glycogenolysis. J. Clin. Invest. 87:133-138.

28. Bradford, M.M. 1976. A rapid and sensitive method for the quantitation of microgram quantities of protein utilizing the principle of protein-dye binding. Anal. Biochem. 72:248-254.

29. Firth, J.D., and P.J. Ratcliffe. 1992. Organ distribution of the three rat endothelin messenger RNAs and the effects of ischemia on renal gene expression. J. Clin. Invest. 90:1023-1031.

30. O'Reilly, G., D.S. Charnock-Jones, J.J. Morrison, I.T. Cameron, A.P. Davenport, and S.K. Smith. 1993. Alternatively spliced mRNAs for human en- dothelin-2 and their tissue distribution. Biochem. Biophys. Res. Commun. 193: 834-840.

31. Takada, J., M. Hata, K. Okada, K. Matsuyama, and M. Yano. 1992. Biochemical properties of endothelin converting enzyme in renal epithelial cell lines. Biochem. Biophys. Res. Commun. 182:1383-1388.

32. Xu, D., N. Emoto, A. Giaid, C. Slaughter, S. Kaw, D. deWit, and M Yanagisawa. 1994. ECE-1: a membrane-bound metalloprotease that catalyzes the proteolytic activation of big endothelin-1. Cell. 78:473-485.

33. Emoto, N., and M. Yanagisawa. 1995. Endothelin-converting enzyme-2 is a membrane-bound, phosphoramidon-sensitive metalloprotease with acidic pH optimum. J. Biol. Chem. 270:15262-15268.

34. Gratton, J.P., G.A. Rae, A. Claing, S. Télémaque, and P. D'OrléansJuste. 1995. Different pressor and bronchoconstrictor properties of human bigendothelin-1, 2 (1-38), and 3 in ketamine/xylazine-anaesthetized guinea-pigs. Br. J. Pharmacol. 114:720-726.

35. Fitz, J.G., S. Basavappa, J. McGill, O. Melhus, and J.A. Cohn. 1993. Regulation of membrane chloride currents in rat bile duct epithelial cells. $J$. Clin. Invest. 91:319-328.

36. Dray-Charier, N., A. Paul, D. Veissière, M. Mergey, J.-Y. Scoazec, J. Capeau, C. Brahimi-Horn, and C. Housset. 1995. Expression of cystic fibrosis transmembrane conductance regulator in human gallbladder epithelial cells. Lab. Invest. 73:828-836.

37. Peters, R.H.P.C., J.H. van Doorninck, P.J. French, R. Ratcliff, M.J. Evans, W.H. Colledge, J. Bijman, and B.J. Scholte. 1997. Cystic fibrosis transmembrane conductance regulator mediates the cyclic adenosine monophosphate-induced fluid secretion but not the inhibition of resorption in mouse gallbladder epithelium. Hepatology. 25:270-277.

38. Scoazec, J.-Y., A.-F. Bringuier, J.F. Medina, E. Martinez-Anso, D. Veissière, G. Feldmann, and C. Housset. 1997. The plasma membrane polarity of human biliary epithelial cells: in situ immunohistochemical analysis and functional implications. J. Hepatol. 26:543-553.

39. Illek, B., J.R. Yankaskas, and T.E. Machen. 1997. cAMP and genistein stimulate $\mathrm{HCO}_{3}{ }^{-}$conductance through CFTR in human airway epithelia. Am. J. Physiol. 272:L752-L761.

40. Hildebrand, P., J.E. Mrozinski, S.A. Mantey, R.J. Patto, and R.T. Jensen. 1993. Pancreatic acini possess endothelin receptors whose internalization is regulated by PLC-activating agents. Am. J. Physiol. 264:G984-G993.

41. Aramori, I., and S. Nakanishi. 1992. Coupling of two endothelin receptor subtypes to differing signal transduction in transfected Chinese hamster ovary cells. J. Biol. Chem. 267:12468-12474.

42. James, A.F., L.-H. Xie, Y. Fujitani, S. Hayashi, and M. Horie. 1994. Inhibition of the cardiac protein kinase A-dependent chloride conductance by endothelin-1. Nature. 370:297-300.

43. Pinzani, M., S. Milani, R. De Franco, C. Grappone, A. Caligiuri, A. Gentilini, C. Tosti-Guerra, M. Maggi, P. Failli, C. Ruocco, and P. Gentilini. 1996. Endothelin 1 is overexpressed in human cirrhotic liver and exerts multiple effects on activated hepatic stellate cells. Gastroenterology. 110:534-548.

44. Schwiebert, E.M., N. Kizer, D.C. Gruenert, and B.A. Stanton. 1992. GTP-binding proteins inhibit cAMP activation of chloride channels in cystic fibrosis airway epithelial cells. Proc. Natl. Acad. Sci. USA. 89:10623-10627.

45. McGill, J.M., T.W. Gettys, S. Basavappa, and J.G. Fitz. 1993. GTP-binding proteins regulate high conductance anion channels in rat bile duct epithelia cells. J. Membr. Biol. 133:253-261.

46. Rockey, D.C., L. Fouassier, J.J. Chung, A. Carayon, P. Vallée, C. Rey, and C. Housset. 1998. Cellular localization of endothelin-1 and increased production in liver injury in the rat: potential for autocrine and paracrine effects on stellate cells. Hepatology. 27:472-480.

47. Bluhm, R.E., M.G. Frazer, M. Vore, W. Pinson, and K.F. Badr. 1993. Endothelins 1 and 3: potent cholestatic agents secreted and excreted by the liver that interact with cyclosporine. Hepatology. 18:961-968. 